\title{
Mencetak SDM Unggul di UPTD BLKIP Disnakeresdm Provinsi Bali
}

\author{
Ida Bagus Ngurah Arda \\ UPTD BLKIP Disnakeresdm Provinsi Bali \\ Email: uptbpkad@gmail.com
}

\begin{abstract}
Good quality of human resources (HR) needs to be prepared in gacing the Industrial Revolution 4.0 in which one of the ways is by job training/vocational training. Vocational training needs to get important attention especially in Bali because it has flexibility in encouraging changes in community skills. The Provincial Government of Bali through the Unit Pelaksana Teknis Bidang Pelatihan yaitu UPTD Balai Latihan Kerja Industri dan Pariwisata, Dinas Tenaga Kerja dan Energi Sumber Daya Mineral Provinsi Bali, conduct skills training for the workforce in various vocational fields, both in the industrial and tourism fields, which has the aim of forming a workforce skilled, competent, and productive and in accordance with the needs of the workforce. There are three important stages that must be done in improving the quality of human resources through training and development activities. The first stage is identification of training needs, the second stage is training and development, the third stage is evaluation.
\end{abstract}

Keywords: human resource quality, job training, good quality of human resources

\section{LATAR BELAKANG}

Isu revolusi industri 4.0 perlu mendapat perhatian yang serius sehingga kita dapat mempersiapkan diri untuk menjawab tantangan tersebut. Sumber daya yang kompeten adalah salah satu faktor utama penentu keberhasilan transformasi era 4.0 tersebut, karena itu peningkatan kualitas sumber daya manusia (SDM) perlu diprioritaskan.

SDM memiliki peranan penting dalam pembangunan nasional. Hal ini karena SDM selaku subyek atau pelaku akan menentukan keberhasilan pencapaian tujuan pembangunan nasional. Oleh karena itu penyiapan SDM harus dilakukan secara terencana, terkoordinasi dan dilakukan dengan langkah-langkah yang strategis. Perencanaan penyiapan SDM diorientasikan untuk menghasilkan SDM yang memiliki daya saing. Peningkatan daya saing SDM dapat dilakukan dengan berbagai upaya, antara lain melalui pendidikan, pelatihan kerja dan pengalaman di tempat kerja. Pendidikan dan pelatihan kerja harus mampu mempersiapkan sumber daya manusia Indonesia yang mempunyai kualitas, keterampilan, profesionalisme dan kompetensi yang tinggi serta relevan dengan kondisi dan kebutuhan dunia kerja. Oleh karena itu pendidikan dan pelatihan kerja harus dilakukan secara sinergi dan bermuara kepada peningkatan kompetensi kerja, hal ini sejalan dengan

Visi Gubernur Bali "Nangun Sat Kerthi Loka Bali" melalui Pola Pembangunan Semesta Berencana Menuju Bali Era Baru, khususnya misi ke-6 (enam); Mengembangkan Sumber Daya Manusia yang berdaya saing tinggi berkualitas dan berintegritas, bermutu, profesional dan bermoral serta memiliki jati diri yang kokoh yang dikembangkan berdasarkan nilai-nilai kearifan lokal krama Bali dan Misi ke-8 (delapan) Menghasilkan tenaga kerja yang kompeten, produktif, berkualitas dan 
memiliki daya saing tinggi serta memperluas akses kesempatan kerja di dalam dan di luar negeri. Untuk mewujudkan Sumber Daya Manusia yang berdaya saing, terdapat tiga komponen utama yang penting yaitu standar kompetensi kerja, pendidikan/pelatihan berbasis kompetensi dan sertifikasi kompetensi. Standar kompetensi kerja menjadi acuan dalam pengembangan program pendidikan/pelatihan berbasis kompetensi dan pengembangan sertifikasi kompetensi kerja, bahkan dapat menjadi acuan dalam pengembangan SDM. Melalui pelatihan dan pengembangan, tenaga kerja akan mampu mengerjakan, meningkatkan, mengembangkan pekerjaannya.

Kualitas SDM yang mumpuni dan terampil perlu dipersiapkan dalam menghadapi Revolusi Industri 4.0, salah satu cara yaitu dengan adanya pelatihan kerja/pelatihan vokasi. Pelatihan vokasi perlu mendapat perhatian penting khususnya di Bali karena memiliki kelenturan dalam mendorong perubahan skills di masyarakat.

Pemerintah Provinsi Bali melalui Unit Pelaksana Teknis Bidang Pelatihan yaitu UPTD. Balai Latihan Kerja Industri dan Pariwisata, Dinas Tenaga Kerja dan Energi Sumber Daya Mineral Provinsi Bali melaksanakan Pelatihan Keterampilan bagi Angkatan kerja diberbagai bidang kejuruan baik bidang Industri maupun bidang Pariwisata yang mempunyai tujuan membentuk tenaga kerja yang terampil, kompeten dan produktif serta sesuai dengan kebutuhan dunia kerja.

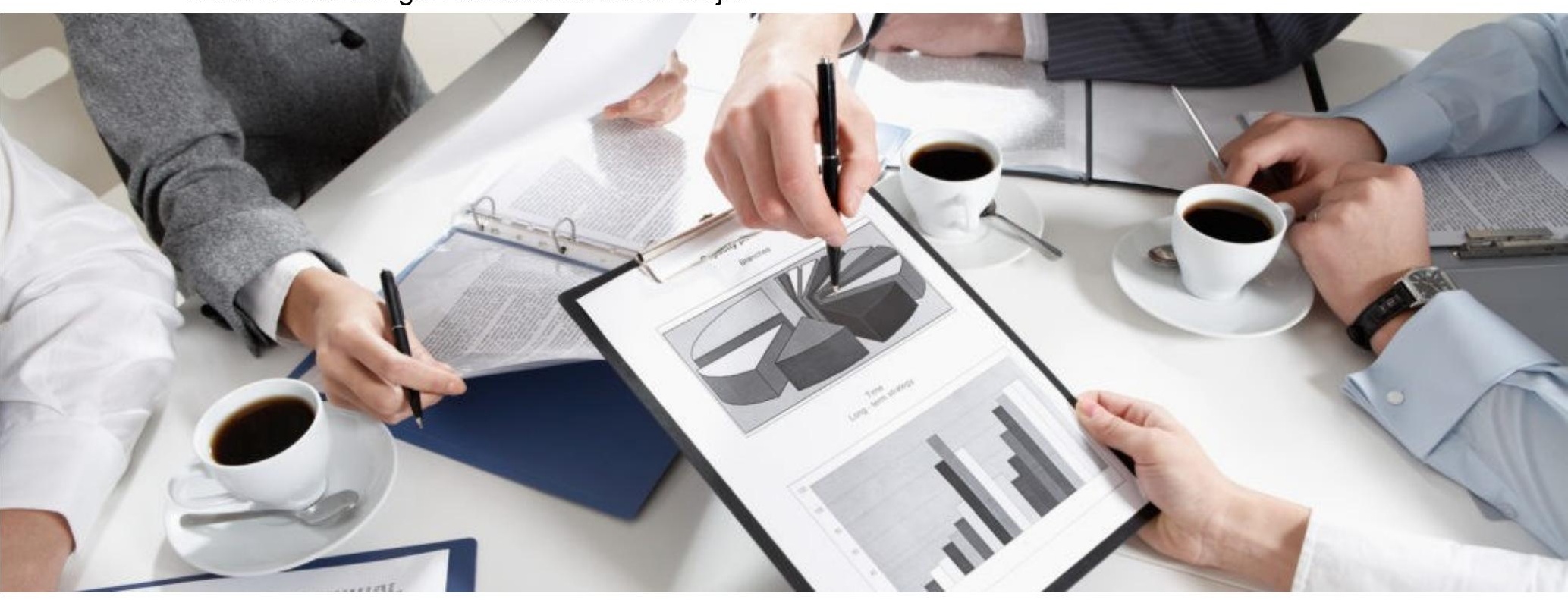

Adapun sasaran dari pelatihan keterampilan ini yaitu calon tenaga kerja dan kelompok-kelompok usaha kecil dan menengah yang berada di seluruh wilayah Provinsi Bali. Lama pelatihan tergantung dari jenis Kejuruan dan tingkat Keterampilan mulai dari 240 Jam Pelatihan sampai 480 Jam Pelatihan. Kejuruan yang terdapat di UPTD BLKIP diantaranya Kejuruan Pariwisata (FB. Product, FB. Service, Housekeeping), Listrik (Teknik Pendingin, Gulung Dinamo, Instalasi Penerangan), Elektronika (Teknisi Audio Video), Automotive (Sepeda Motor), Tata Niaga (Administrasi Perkantoran, Bahasa Inggris, Bahasa Jepang), Aneka Kejuruan (Menjahit, Tata Rias), dan Pertanian (Processing).

Berdasarkan latar belakang di atas, maka muncul ketertarikan untuk membuat makalah yang berjudul "Peningkatan Kualitas Sumber Daya Manusia Bagi Calon 
Tenaga Kerja Melalui Pelatihan Kerja untuk Mencetak SDM Unggul di UPTD BLKIP Disnakeresdm Provinsi Bali". Masalah yang mendasari pembuatan karya tulis ini adalah (1) Bagaimana peranan pelatihan dalam meningkatkan kualitas Sumber Daya Manusia? (2) Bagaimana tahapan proses pengembangan kualitas Sumber Daya Manusia melalui pelatihan kerja di UPTD BLKIP Disnakeresdm Provinsi Bali?

Tujuan dari pembuatan makalah ini adalah: (1) Untuk mengetahui peranan pelatihan dalam meningkatkan kualitas Sumber Daya Manusia. (2) Mengkaji tahapan proses pengembangan kualitas Sumber Daya Manusia melalui pelatihan kerja/pelatihan vokasi. Adapun manfaat dari pembuatan makalah ini terdiri atas manfaat teoritis dan praktis. Adapun manfaat teoritis dari penyusunan makalah ini adalah untuk mengembangkan kazanah pengetahuan dalam bidang Pelatihan dan SDM. Sementara manfaat praktisnya adalah sebagai berikut: (1) Bagi pemerintah, makalah ini diharapkan dapat membantu dalam melaksanakan kegiatan pelatihan sehingga dapat mewujudkan SDM unggul. (2) Bagi masyarakat, makalah ini diharapkan dapat memberikan gambaran bagaimana proses pelatihan dalam meningkatkan Kompetensi (skill, knowledge, attitude), yang nantinya dapat dimanfaatkan untuk bersaing di dunia kerja. (3) Bagi penulis lain, makalah ini diharapkan dapat bermanfaat sebagai salah satu sumber referensi ketika ingin menulis makalah yang sejenis.

\section{PEMBAHASAN}

\section{Peranan Pelatihan dalam Meningkatkan Kualitas SDM}

Pengembangan SDM merupakan suatu istilah yang digunakan untuk menggambarkan suatu pendekatan bersifat terintegrasi dan holistik dalam mengubah prilaku orang-orang yang terlibat dalam suatu proses pekerjaan, dengan menggunakan serangkaian teknik dan strategi belajar yang relevan (Megginson, Joy-Mattews, dan Banfield, 1993). Konsep ini mengandung makna adanya berbagai unsur kegiatan selama terjadinya proses mengubah prilaku, yaitu adanya unsur Pendidikan dan pelatihan, adanya unsur belajar, dan perkembangan. Unsur Pendidikan dan pelatihan dimaksudkan untuk menentukan teknik dan strategi yang relevan untuk mengubah prilaku. Unsur belajar dimaksudkan untuk menggambarkan proses terjadinya interaksi antara individu dengan lingkungan, termasuk dengan pendidik/instruktur/trainer. Adapun unsur perkembangan dimaksudkan sebagai proses gradual dalam perubahan dari suatu keadaan, misalnya dari keadaan tidak dimilikinya kompetensi menjadi keadaan memiliki kompetensi, yang terjadi dalam jangka waktu tertentu. Kompetensi dalam hal ini ditandai oleh dikuasainya Skill, Knowledge, Attitude oleh seseorang pada bidang pekerjaan tertentu.

Pengembangan SDM yang membawa misi sebagaimana disebutkan di atas difokuskan pada peningkatan ketahanan dan kompetensi setiap individu yang terlibat atau akan terlibat dalam proses pembangunan. Peningkatan ketahanan dan kompetensi ini di antaranya dilaksanakan melalui Pendidikan dan pelatihan. Bila dikaitkan dengan pengembangan SDM dalam rangka meningkatkan kemampuan menyesuaikan diri, Pendidikan dan pelatihan juga merupakan upaya meningkatkan derajat kompetensi dengan tujuan agar pesertanya adaptable terhadap berbagai perubahan dan tantangan yang dihadapi. Selain itu, pendidikan yang diselenggarakan seharusnya juga memberi bekal-bekal kemampuan dan keterampilan untuk melakukan 
suatu jenis pekerjaan tertentu yang dibutuhkan agar dapat berpartisipasi dalam pembangunan (Boediono, 1992). Program semacam ini harus dilaksanakan dan disesuaikan dengan keperluan serta usaha yang mengarah kepada antisipasi berbagai perubahan yang terjadi, baik di masa kini maupun yang akan datang (Han, 1994; Dertouzas, Lester, dan Solow, 1989).

Sebagaimana dijelaskan di atas, pembangunan pada dasarnya merupakan suatu proses melakukan perubahan, dalam rangka perbaikan, untuk meningkatkan kesejahteraan rakyat dan kualitas sumber daya manusia (SDM). Kesejahteraan terkait dengan terpenuhinya kebutuhan dasar hidup rakyat, baik material maupun mental dan spiritual. Adapun kualitas SDM terkait dengan derajat kemampuan, termasuk kreatifitas, dan moralitas pelaku-pelaku pembangunan. Atas dasar ini, proses perubahan yang diupayakan melalui pembangunan seharusnya menjangkau perbaikan semua sektor secara menyeluruh dan berimbang, pada satu sisi, dan pada sisi lain merupakan upaya meningkatkan kualitas SDM.

Perbaikan pemenuhan kebutuhan dasar rakyat adalah fokus dari pembangunan sektor ekonomi, dengan tujuan meningkatkan pemenuhan kebutuhan yang bersifat fisik dan material, baik kebutuhan primer, sekunder, tertier maupun kuarter. Pemenuhan kebutuhan ini seharusnya seimbang dengan pemenuhan kebutuhan mental dan spiritual. Bebas dari rasa takut, adanya rasa aman, dihargai harkat dan martabatnya, dilindungi kebebasan dan hak-haknya, serta tersedianya kesempatan yang sama untuk mewujudkan cita-cita dan potensi diri adalah bentukbentuk kebutuhan mental yang seharusnya diperbaiki kondisinya melalui pembangunan. Adapun pemenuhan kebutuhan spiritual terkait dengan kebebasan dan ketersediaan prasarana, sarana dan kesempatan untuk mempelajari, mendalami dan menjalankan ajaran agama yang dianut, sehingga komunikasi dengan Sang Pencipta dapat terpelihara.
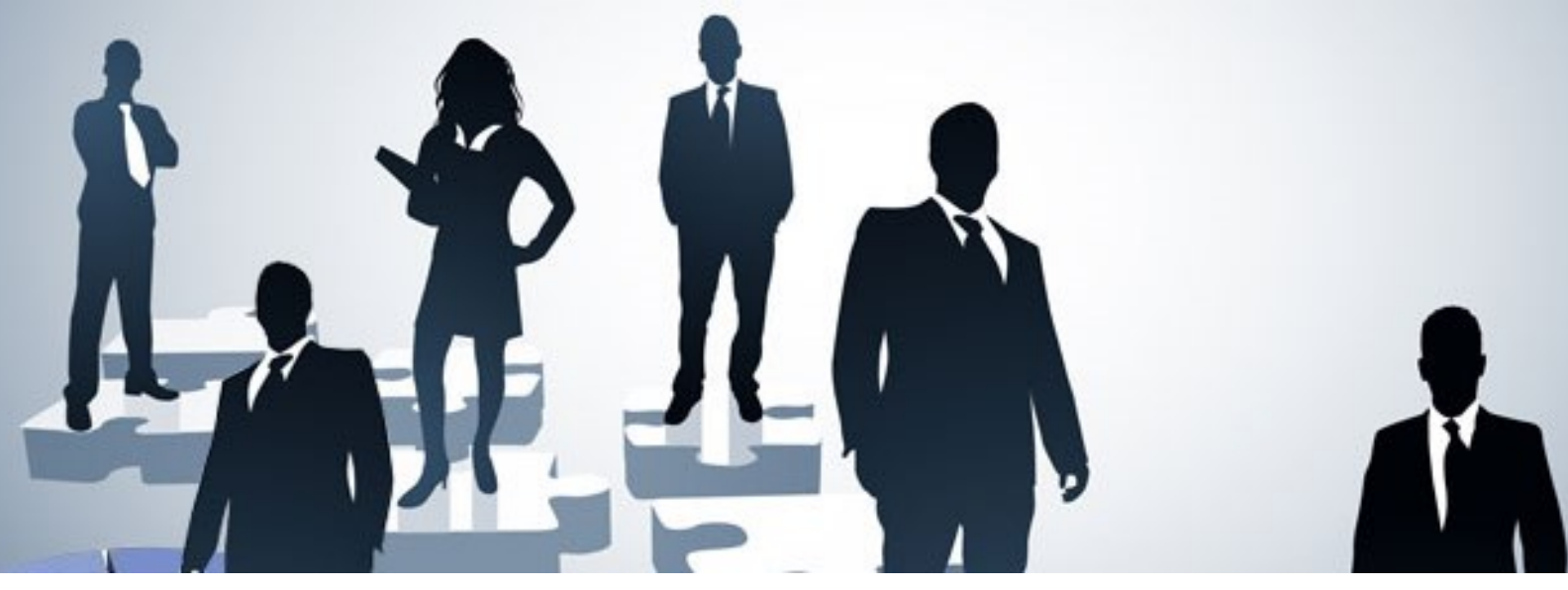

Pada sisi peningkatan kualitas SDM, pembangunan diarahkan untuk menjadikan rakyat negeri ini kreatif, menguasai serta mampu mengembangkan ilmu pengetahuan, teknologi dan seni (IPTEKS), dan memiliki moralitas. Kreatifitas diperlukan untuk bisa bertahan hidup dan tidak rentan dalam menghadapi berbagai kesulitan. Dengan kreatifitas, seseorang menjadi dinamis dan bisa menemukan jalan keluar yang positif ketika menghadapi kesulitan atau masalah. 
Penguasaan dan kemampuan mengembangkan IPTEKS sangat dibutuhkan untuk peningkatan taraf hidup, dan agar bangsa ini bisa disandingkan dan ditandingkan dengan bangsa-bangsa lain. Ini mengingat, globalisasi dalam berbagai bidang kehidupan sudah tidak bisa dihindari dan berdampak pada terjadinya persaingan yang ketat, baik dalam kehidupan sosial, ekonomi, maupun politik. Untuk bisa memasuki pergaulan dalam kehidupan global (persandingan dengan masyarakat global) maupun untuk meraih keberhasilan dalam berbagai kesempatan yang tersedia (pertandingan dalam kehidupan global) diperlukan penguasaan dan kemampuan mengembangkan IPTEKS. Adapun moralitas sangat diperlukan agar dalam menjalani kehidupannya prilaku bangsa ini dikendalikan oleh nilai-nilai kebenaran dan keadilan yang bersifat nasional dan universal. Karena nilai-nilai ini berkait dengan batas-batas antara baik dan tidak baik, benar dan tidak benar, serta antara yang menjadi haknya dan bukan haknya, maka tingginya moralitas dapat meningkatkan keterpercayaan dan keandalan individu dan masyarakat, baik di mata bangsanya sendiri maupun dalam pergaulan global. Jadi, kualitas SDM bukan hanya ditentukan oleh kemampuan dan kreativitasnya saja tetapi juga oleh derajat moralitasnya. Selain berkaitan dengan sistem masyarakat secara umum, kualitas SDM mempunyai keterkaitan erat dengan kualitas pendidikan sekolah. Karena SDM berkualitas adalah keluaran sistem Pendidikan dan pelatihan, proses pendidikan dan pelatihan harusnya menjadikan kreativitas, penguasaan dan kemampuan mengembangkan IPTEKS, serta moralitas sebagai acuan dasar. Unsur penguasaan dan kemampuan mengembangkan IPTEKS bisa dicapai melalui proses pembelajaran sejumlah mata ajaran secara berjenjang.

Adapun unsur moralitas dibangun melalui proses yang kompleks, yang mengutamakan pada pembentukan sikap yang berkait dengan norma dan nilai-nilai. Unsur ini bisa juga dirajut melalui isi berbagai mata ajaran, tidak mesti menjadi suatu mata ajaran tersendiri dalam kurikulum. (Fogarty, 1991).

Persoalan ketenagakerjaan selalu mendapat perhatian yang serius dari berbagai kalangan, baik pemerintah, swasta maupun dari masyarakat. Kompleksitas permasalahan ketenagakerjaan ini dapat dipandang sebagai suatu upaya masingmasing individu untuk memperoleh dan mempertahankan hak-hak kehidupan yang melekat pada manusia agar memenuhi kebutuhan demi kelangsungan hidup.

Tujuan pembangunan nasional, yaitu terwujudnya masyarakat Indonesia yang damai, demokratis, berkeadilan dan berdaya saing maju dan sejahtera dalam wadah negara kesatuan republik indonesia yang didukung oleh manusia yang sehat, mandiri dan bertakwa kepada Tuhan yang Maha Esa.

Dari tujuan tersebut tercermin bahwa sebagai titik sentral pembangunan adalah pemberdayaan sumber daya manusia termasuk tenaga kerja, baik sebagai sasaran pembangunan maupun sebagai pelaku pembangunan. Dengan demikian, pembangunan ketenagakerjaan merupakan salah satu aspek pendukung keberhasilan pembangunan nasional. Di sisi lain, terdapat beberapa permasalahan yang dihadapi dalam pelaksanaan pembangunan nasional tersebut, khususnya dibidang ketenagakerjaan, sehingga diperlukan kebijakan dan upaya dalam mengatasinya.

Sehubungan hal tersebut di atas pengembangan SDM di Indonesia dilakukan melalui tiga jalur utama, yaitu pendidikan, pelatihan dan pengembangan karir di tempat kerja. 
Jalur pendidikan merupakan tulang punggung pengembangan SDM yang dimulai dari tingkat dasar sampai perguruan tinggi. Sementara itu, jalur pelatihan dan pengembangan karir di tempat kerja merupakan jalur suplemen dan komplemen terhadap pendidikan. Pelatihan (training) merupakan proses pembelajaran yang melibatkan perolehan keahlian, konsep, peraturan, atau sikap untuk meningkatkan kinerja tenaga kerja (Simamora, 2006: 273). Menurut pasal I ayat 9 Undang-undang No. 13 Tahun 2003. Pelatihan kerja adalah keseluruhan kegiatan untuk memberi, memperoleh, meningkatkan, serta mengembangkan kompetensi kerja, produktivitas, disiplin, sikap, dan etos kerja pada tingkat ketrampilan dan keahlian tertentu sesuai dengan jenjang dan kualifikasi jabatan dan pekerjaan.

Arah pembangunan SDM di Indonesia ditujukan pada pengembangan kualitas SDM secara komprehensif meliputi aspek kepribadian dan sikap mental, penguasaan ilmu dan teknologi, serta profesionalisme dan kompetensi yang ke semuanya dijiwai oleh nilai-nilai religius sesuai dengan agamanya. Dengan kata lain, pengembangan SDM di Indonesia meliputi pengembangan kecerdasan akal (IQ), kecerdasan sosial (EQ) dan kecerdasan spiritual (SQ).

Dalam rangka pengembangan SDM di Indonesia, banyak tantangan yang harus dihadapi. Tantangan pertama adalah jumlah penduduk yang besar, yaitu sekitar 216 juta jiwa. Tantangan kedua adalah luasnya wilayah indonesia yang terdiri dari 17.000 pulau dengan penyebaran penduduk yang tidak merata. Tantangan ketiga adalah mobilitas penduduk yang arus besarnya justru lebih banyak ke pulau Jawa dan ke kota-kota besar.

Berbagai tantangan seperti itu, memerlukan konsep, strategi dan kebijakan yang tepat agar pengembangan SDM di Indonesia dapat mencapai sasaran yang tepat secara efektif dan efisien. Hal ini penting dilakukan karena peningkatan kualitas SDM Indonesia tidak hanya untuk meningkatkan produktivitas dan daya saing di dalam maupun diluar negeri, tetapi juga untuk meningkatkan kesejahteraan dan pemerataan penghasilan bagi masyarakat.

Namun, terlepas dari permasalahan tersebut, tidak dapat dipungkiri bahwa Lembaga Pelatihan Kerja memiliki peranan yang penting dalam mengembangkan SDM. Hal ini karena setiap lembaga pelatihan umumnya menerapkan system pelatihan berbasis kompetensi (PBK). Pelatihan Berbasis Kompetensi yang selanjutnya disingkat PBK adalah pelatihan kerja yang menitikberatkan pada penguasaan kemampuan kerja yang mencakup pengetahuan, keterampilan, dan sikap sesuai dengan standar yang ditetapkan dan persyaratan di tempat kerja. Berdasarkan hal tersebut, jelaslah bahwa apa yang dilatihkan di BLK/LPK tentu akan sesuai dengan kebutuhan industry, sehingga link and match dapat terwujud.

\section{Proses Pengembangan Kualitas SDM melalui Pelatihan Kerja di UPTD BLKIP Disnakeresdm Provinsi Bali}

UPTD. Balai Latihan Kerja Industri dan Pariwisata yang merupakan salah satu Unit Pelaksana Teknis Daerah (UPTD) Dinas Tenaga Kerja dan Energi Sumber Daya Mineral Provinsi Bali berada di bawah dan bertanggung jawab kepada Kepala Disnaker dan Energi Sumber Daya Mineral Provinsi Bali, yang mempunyai tujuan membentuk tenaga kerja yang terampil, kompeten dan produktif serta sesuai dengan kebutuhan dunia kerja. 
a. Tujuan UPTD BLKIP adalah Setiap orang yang sudah mendapat pelatihan keterampilan mampu untuk bekerja sesuai dengan job yang diisyaratkan, baik melalui hubungan kerja maupun berwirausaha/usaha mandiri.

b. Sasaran Pelatihan di UPTD BLKIP adalah Calon tenaga kerja dan kelompok kelompok usaha kecil dan menengah di seluruh wilayah Provinsi Bali.

c. Tugas UPTD. BLK-IP BALI adalah Melaksanakan Pelatihan Keterampilan bagi angkatan kerja diberbagai bidang kejuruan baik bidang Industri maupun bidang Pariwisata.

Menurut (Simamora, 2006: 278), terdapat lima jenis pelatihan yang dapat diselenggarakan:

1. Pelatihan Keahlian

Pelatihan keahlian (skils training) merupakan pelatihan yang sering di jumpai dalam organisasi. Program pelatihaannya relatif sederhana yaitu kebutuhan atau kekuragan diidentifikasi rnelalui penilaian yang jeli. Kriteria penilalan efekifitas pelatihan juga berdasarkan pada sasaran yang diidentifikasi dalam tahap penilaian.

2. Pelatihan Ulang

Pelatihan ulang (retraining) adalah Pelatihan yang diberikan kepada para karyawan untuk menghadapi tuntutan kerja yang berubah-ubah. Seperti tenaga kerja instansi pendidikan yang biasanya bekerja menggunakan mesin ketik manual mungkin harus dilatih dengan mesin computer atau akses internet

3. Pelatihan Lintas Fungsional

Pelatihan lintas fungsional (cross functional training) melibatkan pelatihan karyawan untuk melakukan aktivitas kerja dalam bidang lainnya selain pekerjaan yang ditugaskan.

4. Pelatihan Tim

Pelatihan tim merupakan bekerjasama terdiri dari sekelompok Individu untuk menyelesaikan pekerjaan demi tujuan bersama dalam sebuah tim kerja.

5. Pelatihan Kreativitas

Pelatihan kreatifitas (creativity training) berlandaskan pada asumsi hahwa kreativitas dapat dipelajari. Maksudnya tenaga kerja diberikan peluang untuk mengeluarkan gagasan sebebas mungkin yang berdasar pada penilaian rasional dan biaya dan kelayakan.

Sebelum pelatihan diselenggarakan, diperlukan analisa kebutuhan pelatihan sesuai dengan peta potensi kebutuhan dunia usaha dan industri sebagai langkah/tahapan penilaian dari proses pelatihan. Menurut (Sjafri, 2003: 140). setelah tahap analisis kebutuhan dilakukan, maka harus melakukan beberapa tahapan berikutnya:

1. Penilaian kebutuhan pelatihan

- Penilaian kebutuhan perusahaan

- Penilaian kebutuhan tugas

- Penilaian kebutuhan karyawan

2. Perumusan tujuan pelatihan

Perumusan tujuan pelatihan harus ada keterkaitan antara input, output, outcame dan impact dari pelatihan itu sendiri.

3. Prinsip-prinsip pelatihan

- Partisipatif 
- Pendalaman

- Relevansi

- Pengalihan

- Umpan balik

- Suasana nyaman

- Memiliki kriteria

4. Merancang dan menyeleksi prosedur pelatihan

- Pelatihan instruksi pekerjaan

- Perputaran pekerjaan

- Magang dan pelatihan

- Kuliah dan presentasi

- Permainan peran dan pemodelan prilaku

- Studi kasus

- Simulasi

- Studi mandiri dan pembelajaran program

- Pelatihan laboratorium

- Pembelajaran aksi

Menurut (Gomes, 2003: 204) terdapat paling kurang tiga tahapan utama dalam pelatihan dan pengembangan, yakni: penentuan kebutuhan pelatihan, desain program pelatihan, evaluasi program pelatihan.

1. Penentuan kebutuhan pelatihan (Training Need Analysis)

Tujuan penentuan kebutuhan pelatihan ini adalah untuk mengumpulkan sebanyak mungkin informasi yang relevan guna mengetahui dan atau/menentukan apakah perlu atau tidaknya pelatihan dalam organisasi tersebut.

Dalam tahapan ini terdapat tiga macam kebutuhan akan pelatihan yaitu:

a. General treatment need, yaitu penilaian kebutuhan pelatihan bagi semua pegawai dalam suatu klasifikasi pekerjaan tanpa memperhatikan data mengenai kinerja dari seseorang pegawai tertentu.

b. Oversable performance discrepancies, yaitu jenis penilaian kebutuhan pelatihan yang didasarkan pada hasil pengamatan terhadap berbagai permasalahan, wawancara, daftar pertanyaan, dan evaluasi/penilaian kinerja, dan dengan cara meminta para pekerja untuk mengawasi sendiri hasil kerjanya sendiri.

c. Future human resources neeeds, yaitu jenis keperluan pelatihan ini tidak berkaitan dengan ketidaksesuaian kinerja, tetapi lebih berkaitan dengan sumberdaya manusia untuk waktu yang akan datang.

2. Mendesain program pelatihan

Setelah adanya kebutuhan sesuai dengan dunia industri maka disusunlah program pelatihan dengan kurikulum dan silabus yang sesuai.

3. Evaluasi program pelatihan

Tujuan dari tahapan ini adalah untuk menguji apakah pelatihan tersebut efektif di dalam mencapai sasaran-sasarannya yang telah ditetapkan. Program pelatihan bisa dievaluasi berdasarkan informasi yang bisa diperoleh pada lima tingkatan:

a. Reactions: Ukuran mengenai reaksi ini didesain untuk mengetahui opini dari para peserta mengenai program pelatihan. Usaha untuk mendapatkan opini para peserta tentang pelatihan ini, terutama didasarkan pada beberapa alasan 
utama, seperti: untuk mengetahui sejauh mana para peserta merasa puas dengan program pelatihan.

b. Learning: Informasi yang ingin diperoleh melalui jenis evaluasi ini adalah mengetahi seberapa jauh para peserta menguasai konsep-konsep, pengetahuan, keterampilan-keterampilan yang diberikan selama pelatihan.

c. Behaviors: Perilaku dari para peserta, sebelum dan sesudah pelatihan, dapat dibandingkan guna mengetahui tingkat pengaruh pelatihan terhadap perubahan performansi mereka. Langkah ini penting karena sasaran dari pelatihan adalah untuk mengubah perilaku atau performansi para peseerta pelatihan setelah diadakan program pelatihan.

d. Organizational result: tujuan dari pengumpulan informasi pada level ini adalah untuk menguji dampak pelatihan terhadap kelompok kerja atau organisasi secara keseluruhan.

e. Cost effectivity: ini dimaksudkan untuk mengetahui besarnya biaya yang dihabiskan bagi program pelatihan, dan apakah besarnya biaya untuk pelatihan tersebut terhitung kecil atau besar dibandingkan biaya yang timbul dari permasalah yang dialami oleh organisasi.

Sedangkan menurut Dessler (2004: 217), program pelatihan terdiri dari lima tahapan:

1. Pertama: Langkah analisis kebutuhan, yaitu mengetahui keterampilan kerja spesifik yang dibutuhkan, menganalisa keterampilan dan kebutuhan calon yang akan dilatih, dan mengembangkan pengetahuan khusus yang terukur serta tujuan prestasi.

2. Kedua: Merancang instruksi, yaitu untuk memutuskan, menyusun, dan menghasilkan isi program pelatihan, termasuk buku kerja, latihan dan aktivitas.

3. Ketiga: langkah validasi, yaitu program pelatihan dengan menyajikan kepada beberapa orang yang bisa mewakili.

4. Keempat: menerapkan program, yaitu melatih karyawan yang ditargetkan.

5. Kelima: Langkah evaluasi dan tindak lanjut, dimana manejemen menilai keberhasilan atau kegagalan program tersebut.

Jenis Program Pelatihan di UPTD BLKIP adalah sebagai berikut.

1. Program Pelatihan Berbasis Kompetensi

Adalah sistem pelatihan kerja dengan berbagai kejuruan yang dilaksanakan dengan mengacu pada Standar Kualifikasi Kerja Nasional Indonesia (SKKNI) yang sesuai dengan kebutuhan industri/pasar kerja. Contohnya: Pelatihan Kejuruan Perhotelan (FB Service, FB Product, dan Housekeeping)

2. Program Pelatihan Berbasis Masyarakat

Adalah Pelatihan Kerja yang dilaksanakan berdasarkan kebutuhan pasar kerja dengan berbagai kejuruan yang diarahkan untuk penempatan baik bekerja pada orang lain maupun mandiri. Contohnya: Pelatihan Kejuruan Processing Hasil Pertanian

3. Program Pelatihan Keliling Mobile Training Unit (MTU)

Adalah Pelatihan kerja yang dilaksanakan berdasarkan kebutuhan masyarakat didaerah Pedesaan (diluar BLK-IP Bali). Contohnya: Pelatihan Kejuruan Menjahit, Sepeda Motor dan Tata Rias

4. Pelatihan Kerjasama Pihak III 
Adalah Pelatihan berdasarkan permintaan pihak III (Lembaga Pemerintah, Pendidikan Swasta dan Masyarakat umum/perorangan) di mana seluruh biaya pelatihan ditanggung oleh Pihak III. Contohnya: Pelatihan yang bekerja sama dengan Lembaga Pemasyarakatan, Badan Narkotika Nasional, dan beberapa LPK Swasta

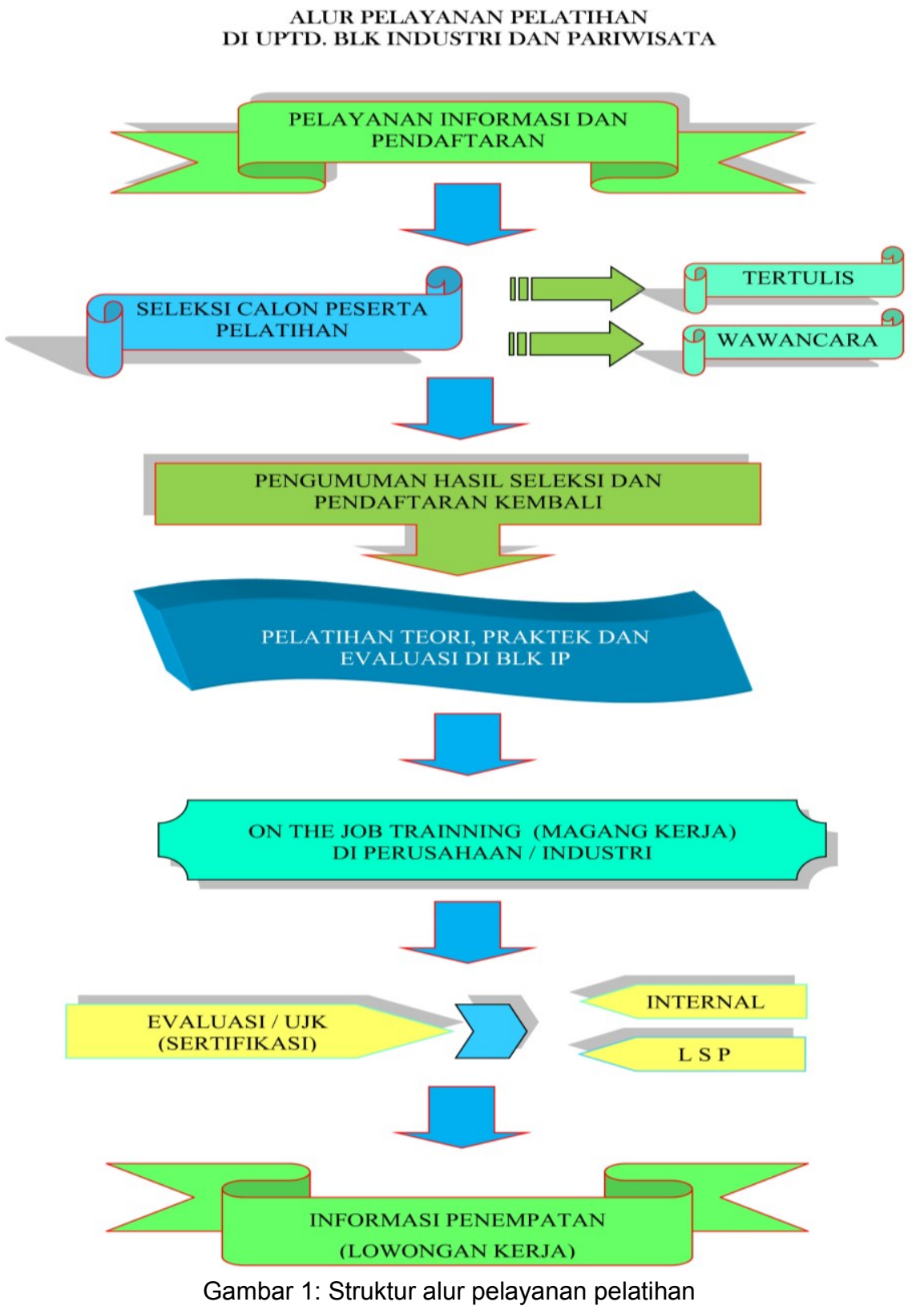

Lama Pelatihan tergantung dari jenis kejuruan dan tingkat keterampilan:

- 240 Jam Pelatihan $\pm 11 / 2$ (satu setengah) bulan

- 320 Jam Pelatihan \pm 2 (dua) bulan

- 480 Jam Pelatihan \pm 3 (tiga) bulan

Setelah mengikuti pelatihan sesuai dengan jam pelatihan tersebut diatas baik teori maupun praktik, peserta diwajibkan mengikuti On the Job Training (OJT) di dunia 
usaha/industri untuk memantapkan keterampilan dan menyesuaikan diri di dunia kerja. Jenis-Jenis Kejuruan di UPTD BLKIP

1. Kejuruan Pariwisata

A. FB Division

- Kitchen \& Pastry

- Restaurant \& Bar

- Engineering

B. Room Division

- HouseKeeping/Laundry

2. Listrik

- Teknik Pendingin

- Gulung Dinamo

- Instalasi Penerangan

2. Elektronika

- Teknisi Audio Video

3. Automotive

- Sepeda Motor

4. Tata Niaga

- Administrasi Perkantoran/Sekretaris

5. ANEKA KEJURUAN

- Menjahit

- Tata Rias

6. PERTANIAN

- Processing

\section{SIMPULAN}

Pelatihan lebih terarah pada peningkatan kemampuan dan keahlian SDM organisasi yang berkaitan dengan jabatan atau fungsi yang menjadi tanggung jawab individu yang bersangkutan saat ini (current job oriented). Sasaran yang ingin dicapai dari suatu program pelatihan adalah peningkatan kinerja individu dalam jabatan atau fungsi saat ini.

Pengembangan lebih cenderung bersifat formal, menyangkut antisipasi kemampuan dan keahlian inividu yang harus dipersiapkan bagi kepentingan jabatan yang akan datang.

Pelatihan dan pengembangan merupakan salah satu solusi terhadap sejumlah problem penurunan kualitas kinerja organisasi atau lembaga dan instansi yang disebabkan oleh penurunan kemampuan dan keusangan keahlian yang dimiliki oleh karyawan atau tenaga kerja atau pencari kerja.

Pelatihan dan pengembangan bukanlah solusi utama yang dapat menyelesaikan semua persoalan organisasi, lembaga atau sebuah instansi. Tetapi mengarah pada peningkatan kinerja para karyawan atau tenaga kerja atau pencari kerja yang baik dan benar. Tujuan pelatihan dan pengembangan adalah untuk merubah sikap, perilaku, pengalaman dan performansi kinerja.

Pelatihan merupakan serangkaian aktivitas yang dirancang untuk meningkatkan keahlian, pengetahuan, pengalaman, ataupun perubahan sikap 
seseorang inidividu. Dalam pelaksanaan pelatihan akan tercipta suatu lingkungan di mana peserta pelatihan dapat memperoleh dan mempelajari sikap, kemampuan, keahlian, pengetahuan yang berkaitan dengan pekerjaan.

Meningkatkan kualitas SDM adalah menyiapkan individu untuk mengemban tanggung jawab yang berbeda atau lebih tinggi. Pengembangan biasanya berkaitan dengan peningkatan kemampuan intelektual atau emosional yang diperlukan untuk melaksanakan pekerjaan yang lebih baik. Terdapat tiga tahapan penting yang harus dilakukan dalam meningkatkan kualitas SDM melalui kegiatan pelatihan dan pengembangan. Pertama tahapan identifikasi kebutuhan pelatihan, kedua tahapan pelatihan dan pengembangan, ketiga tahapan evaluasi.

\section{DAFTAR PUSTAKA}

Alwi, Syafaruddin. 2000. Manajemen Sumber Daya Manusia. Yogyakarta: BPFE Decenzo, D.A.( 1999). Human recources Managemen. Sixth edition. Newyork: John Wiley \& Sons.Inc.

Dessler, Gary. 2004. Sumber Daya Manusia, Penerjemah Eli Tanya. Jakarta: PT. Indeks. Judul asli Human Resource Managemen. (2003) pretince-Hall, inc, Upper Saddle River. New Jersey.

Gomes, Faustinc C. 2003. Manajemen Suber Daya Manusia. Yogyakarta: CV. Andi Offsetl

Handoko, T. Hani. 2001. Manajemen Personalia dan Sumber Daya Manusia. Yogyakarta: BPFE.

Mangkuprawira. Sjafri. 2003. Mananjemen Sumber Daya Manusia Strategik. Jakarta: Ghalia Indonesia.

Nawawi, Hadari 2005. Manajemen Sumber Dava Manusia. Yogyakarta: Gadjah Mada University Press.

Permenaker 8 Tahun 2014.

Sirnamora, Henry. 2006. Manajemen Sumber Daya Manusia. Yogyakarta: STIE YKPN. Undang-undang No. 13 Tahun 2003. 


\title{
Modal Sosial Pembangunan SDM Masyarakat Bali
}

\author{
I Gusti Ayu Wimba \\ Fakultas Ekonomi Bisnis dan Pariwisata \\ Universitas Hindu Indonesia \\ email: igawimba179@gmail.com
}

\begin{abstract}
During this time, the government and the community in implementing development, explicitly only prioritize economic capital and human capital in an individual perspective only. Not many people have highlighted the role of social capital, which is a necessity, in maintaining the results of development that have been carried out. Mainly, Balinese social capital which is hierarchically shaped through values that are invested from an early age, will grow into an accumulation of social capital which will later contribute positively in maintaining a conducive atmosphere in developing human resources for the Balinese people.
\end{abstract}

Keywords: social capital, development, human resources, Balinese people.

\section{PENDAHULUAN.}

Hampir pada setiap periodisasi perekonomian Indonesia, kita selalu berkutat dengan segala bentuk perencanaan pembangunan yaitu strategi pembangunan dan implementasinya, untuk mencapai masyarakat adil dan makmur selalu saja mendapat hambatan. Artinya, pencapaian tujuan pembangunan, yaitu masyarakat Indonesia seutuhnya yang makmur dan berkeadilan belum pernah terwujud secara sempurna. Yang sering disebut sebagai penyebab adalah, kondisi geografis Indonesia yang sangat luas, sehingga masyarakat belum dapat menikmati hasil pembangunan secara adil dan merata. Untuk melaksanakan pembangunan, diperlukan akumulasi modal dalam wujud modal uang dan asset padat lainnya yang harus diinvestasikan oleh pemerintah untuk mencapai tujuan pembangunan. Dalam hal ini, modal uang dan sejumlah asset lainnya di sebut sebagai economic capital. Untuk dapat mengalokasikan sumber daya ekonomi secara efisien, seperti dalam membuat perencanaan, menganalisis rasio-rasio alokasi dana, Prediksi-predikdi prosfektif atas modal yang diinvestasikan dan untuk mengevaluasi hasil pembangunan, diperlukan sumber daya manusia yang kualitasnya representatif untuk mengemban tugas ini. Kualitas sumber daya manusia secara individual disebut sebagai human capital, yang sejatinya juga memerlukan investasi yang tidak kecil. Untuk dua jenis modal ini (economic capital dan human capital) pemerintah Indonesia sudah dengan sangat efisiendan efektif mengalokasikannya untuk mewujudkan tujuan pembangunan. Dan ketersediaanya sudah memadai bahkan berlebih. Tetapi, untuk memelihara hasil pembangunan, yang direncanakan dan dilaksanakan bertahun-tahun, agaknya memerlukan satu jenis modal lagi yaitu modal sosial (social capital). Perhatian secara mendalam pemerintah dan masyarakat kepada modal sosial dan peranannya dalam pembangunan, agaknya belum mendapat proyeksi secara.proporsional.

Fakta empiric menunjukkan, bahwa hasil pembangunan di Provinsi Bali, selalu lebih cantik dari kondisi pembangunan untuk tingkat nasional. Indikator-indikator kinerja pembangunan Bali seperti pertumbuhan ekonomi, tingkat Inflasi, rasio gini, 
kelompok. Dalam hal ini, modal sosial diakui hanya akan eksis apa bila diperngunakan dalam interaksi kelompok masyarakat.

Hasbullah (2006), unsur pokok modal sosial itu terdiri dari enam dimensi yaitu: 1) Partisipasi dalam suatu jaringan, artinya modal sosial tidak dibangun oleh satu individu, melainkan akan terletak padakecenderungan yang tumbuh dalam suatu kelompok untuk bersosialisasi sebagai nilai yang sangat penting. 2) resiprosity, dalam hal ini modal sosial senantiaa diwarnai oleh kecendrungan untuk saling bertukar kebaikan antar individu dalam suatu kelompok atau antar kelompok. 3) Trust adalah rasa percaya dan mempercayai, atau suatu keinginan untuk mengambil resiko dalam hubungan sosial yang didasari oleh perasaan yakin bahwa orang lain akan melakukan sesuatu seperti yang diharapkan atau paling tidak yang lain tidak akan bertindak yang merugikan diri dan kelompoknya. 4) Norma Sosial sesuatu yang terbentuk akibat adanya Trust dalam suatu kepompok yang akan sangat berperan dalam mengontrol bentuk-bentuk perilaku yang tumbuh dan diharapkan oleh masyarakat. 5) Nilai-nilai adalah suatu ide yang sudah turun temurun diakui dan dianggap benar dan penting oleh sekelompok masyarakat. 6) tindakan yang proaktif adalah keinginan yang kuat dari anggota kelompok untuk tidak saja berpartisipasi, tetapi senantiasa berinisiatif mendahului untuk menemukan tindakan bagi keterlibatan mereka dalam suatu kegiatan kelompok masyarakat.

\section{Modal Sosial Masyarakat Bali}

Proses terbentuknya modal sosial bagi masyarakat Bali, sedikit berbeda dengan apa yang dikemukakan oleh para pakar tentang modal sosial. Untuk masyarakat Bali, secara natural dan hirarkis, unsur-unsur modal sosial yang dimiliki oleh masyarakat Bali adalah: 1) nilai-nilai, 2) norma social, 3) trust, 4) resiprocity, 5) partisipasi dalam jaringan, dan 6) tindakan yang proaktif. Satu per satu pembahasan atas dimensi modal sosial ini adalah sebagai berikut:

Nilai-nilai yang dipakai sebagai anutan yang menuntun tingkah laku masyarakat Bali adalah srada. Salah satu srada yang paling mempengaruhi periklu masyarakat Bali pada umumnya, adalah Karma Pala, yaitu percaya pada adanya hasil perbuatan. Secara umum, masyarakat Bali meyakini bahwa apa yang ditanam, pasti itulah yang dipetik. Atau dengan cara yang paling mudah mengatakannya perbuatan baik pasti akan menghasilkan kebaikan, begitu juga sebaliknya perbuatan buruk pasti akan membuahkan hasil yang buruk juga. Begitulah konsep nilai-nilai hasil perbuatan ditanamkan sejak kecil, yang mengakibatkan sejak usia dini sudah timbul keinginan untuk berbuat yang menyenangkan orang lain. Kebiasaan memperlakukan dengan baik orang lain dalam suatu kelompok, akan menyebabkan terbentuknya semacam norma sosial, yang diakui dan dipatuhi bersama dalam suatu kelompok masyarakat.Demikian juga pada masyarakat Bali.

Norma Sosial akan sangat berperan dalam mengontrol bentuk-bentuk perilaku yang tumbuh dalam masyarakat, yang dalam hal ini adalah masyarakat Bali. Norma sosial adalah sekumpulan aturan yang diharapkan dapat dipatuhi dan diikuti oleh anggota masyarakat sebagai suatu entias sosial. Salah satu norma sosial yang diakui dan dipatuhi oleh masyarakat Bali, seperti "gilik-saguluk sabayan taka", yang diimplementasikan dalam sistem kekerabatan pada satu keluarga besar, satu Banjar Adat dan akhirnya pada satu Desa Pekraman. Konfigurasi norma sosial yang tumbuh di tengah masyarakat Bali juga akan menentukan apakah norma-norma tersebut akan memperkuat kerekatan hubungan antar individu dalam kelompok masyarakat Bali dan akan memberikan dampak positif bagi perkembangan masyarakat. Implementasi norma sosial yang kental dalam masyarakat akan membentuk trust yaitu perilaku saling percaya-mempercayai dalam suatu entitas masyarakat, dalam hal ini masyarakat Bali.

Trust adalah sikap saling mempercayai di masyarakat, yang memungkinkan masyarakat tersebut saling bersatu dengan yang lain dalam suatu interaksi sosial. Berbagai tindakan kolektif yang didasari atas rasa saling percaya yang mendalam akan meningkatkan partisipasi 
masyarakat dalam berbagai ragam bentuk dan dimensi, terutama dalam konteks membangun kemajuan bersama. Masyarakat yang kurang memiliki rasa saling mempercayai akan suit menghindari berbagai kerawanan sosial dan ekonomi yang mengancam. Kahancuran rasa saling percaya di masyarakat akan membuat masyarakat cenderung apatis dan hanya menunggu apa yang akan diberikan pemerintah. Kadar trust masyarakat Bali sangat tinggi.baik kepada sesama warga masyarakat, di keluarga besar, di Banjar, di Desa Pekraman, kepada pemerintah Kabupaten/Kota, Pemerintah Privinsi maupun pemerintah Pusat, sehingga sukup resiten untuk mendapat hasutan dari pihak-pihak yang tidak bertanggungjawab untuk turut berdemonstrasi apa lagi hal-hal yang menyangkut perilaku makar lainnya. Tingkat trust sesama masyarakat Bali relatif tinggi, sehingga di Bali cukup aman dari tindak kerawanan sosial dan ekonomi. Tingkat trust yang tinggi dari suatu masyarakat, akan menumbuhkan perilaku "resiprosity" yang tinnggi pula sebagai modal sosial suatu masyarakat.

Resiprosity adalah kecenderungan untuk saling bertukar kebaikan antar individu dalam suatu kelompok. Pola ini bukan sesuatu yang resiprokal seketika, tetapi adalam kombinasi jangka pendek dan jangka panjang dalam nuansa hidup yang altruis yang bersemangat untuk saling mambantu dan mementingkan kepentingan orang lain. Masyarakat yang memiliki bobot resiprositas yang kuat akan melahirkan kelompok masyarakat yang memiliki modal sosial yang tinggi. Kadar resiprosity masyarakat Bali, terlihat jelas pada saat ada upacara kematian pada Banjar adatnya. Masing-masing individu seakan ingin memberi yang terbaik pada aktivitas keagamaan banjar adatnya. Ada semacam rasa takut ditinggalkan oleh sesama dalam kelompok banjarnya. Istilah pada masyarakat Bali "Takut Kesepekang Banjar". Rasa inilah yang membentuk resiprositas masyarakat Bali, dan akhirnya menumbuhkan jiwa bersemangat untuk berpartisipasi dalam jaringan kekerabatan sesama anggota masyarakat.

Partisipasi dalam jaringan, menjustifikasi bahwa modal sosial tidak dibangun oleh satu ndividu, melainkan terletak pada kecenderungan yang tumbuh dalam kelompok untuk bersosialisasi sebagai bagian yang penting sebagai nilai yang mendasar. Pada masyarakat, secara tradisional sudah terbentuk atas dasar kesamaan garis keturunan, pengalamanpengalaman social yang turun-temurun, dan kepercayaan pada dimesnsi religius yang mengakibatkan kecenderungan memiliki tingkat kohesifitas yang tinggi. Pada tataran ini, ditengarai kelompok masyarakat akan cenderung caupinistis, yang dapat saja menjadi kurang kondusif bagi eksistensi kelompok masyarakat lain. Dalam hal ini, masyarakat Bali diakui mempunyai tingkat partisipasi yang tinggi dan mempunyai kesanggupan yang ditinggi untuk beradaptasi dengan budaya-budaya yang datang dari luar Bali, dan sanggup berakselerasi dengan sempurna, tanpa harus meninggalkan identitas budayanya sendiri. Di sini diakui tingkat partisipasi yang tinggi dari suatu kelompok masyarakat akan menunbuhkan tintakan pro-aktif yang sangat positif bagi kelangsungan hidup masyarakat Bali sendiri.

Tindakan yang pro-aktif adalah modal sosial dalam bentuk keinginan yang kuat dari anggota kelompok untuk tidak saja berpartisipasi, tetapi justru senantiasa mencari jalan bagi keterlibatan mereka dalam suatu kegiatan masyarakat. Identitas yang menandai kelompok masyarakat ini adalah mereka cenderung tidak menyukai bantuan yang sifatnya dilayani, tetapi mengharapkan diberikan pilihan untuk lebih banyak melayani secara proaktif. Pada masyarakat Bali, modal sosial ini terlihat pada kesediaan masyarakat untuk memelihara dan menjaga kebersihan lingkungan, terutama pada fasilitas-fasilitas puklik, seperti Balai Banjar, Setra dan Kahyangan Tiga yang ada di wewengkon desa Pekraman. Secara pro-aktif dalam menjaga keamanan dan ketertiban lingkungan masyarakat, menelisik kemungkinan terindikasi adanya rencana-rencana perilaku subversive yang tidak kondusif dan membahayakan masyarakat dapat juga disebut sebagai bentuk modal sosial masyarakat Bali.

Di era digitalisasi ini, saat kemajuan Artifisial Intelegent (Al) sangat pesat, para pelaku pembangunan seakan ketakutan akan ketinggalan atau digilas oleh kemajuan zaman, sehingga mengarahkan strategi pembanguannya pada penyiapan sumber daya manusia (human capital) dan pembangunan berbagai infrastruktur yang meguras modal uang (economic capital). Dalam 
hal ini, cenderung melupakan perhatian pada kualitas interaksi sosial masyarakat (social capital), dimana keberadaan modal terakhir ini adalah mengkatalis pencapaian pemerataan pembangunan. Di Provinsi Bali, perhatian pemerintah pada pembangunan kualitas interaksi sosial mesyarakat perlu diperhatikan secara proporsional. Sehingga kedepan, tidak ada ketakutan akan kemajuan teknologi, karena seberapapun kecanggihan teknologi sejatinya masih tetap pemerlukan manusia (masyarakat) untuk mengontrol pemanfaatan kemanjuan teknologi. Alih-alih, bisa saja jadi kebablasan, karena kemajuan teknologi tanpa manusia yang arif dan bijak sebagai laeder control atas kemanjuan teknologi.

Era digitalisasi akan membawa masyarakat pada situasi yang ramai dalam kesunyian. Orang dewasa, anak-anak akan cenderung lebih menyukai di tempat yang sepi (didalam kamar yang sangat privasi), dengan sebuah "smart-phone" yang canggih, tetapi merka bisa terhubung ke berbagai situs yang mereka inginkan. Dengan berbagai rogram aplikasi seperti: facebook, watsapp, instagram, games, dan aplikasi lainnya, mereka dapat mengakses berbagai situs sesuai apa yang mereka inginkan. Kenyataan ini, akan secara sistematis, lambat tapi pasti akan membawa masyarakat Bali ke pergeseran pola kehidupan, dari yang semula berpola kolektif, altruis, proaktif penuh inisiatif, menjadi individual yang apatis. Dari semula, lebih menyukai bertukar pikiran di Balai Banjar, menjadi lebih suka menyendiri, menikmati berbagai situs yang dapat diakses secara on-line melalui smart-phone yang ada digemgamannya. Kebiasaan masyarakat yang kurag kondusif ini, lambat laun akan membuat permasalahan yang serius bagi keberadaan masyarakat Bali, yaitu mengubah pola kekerabatan masyarakat yang semula hidup harmonis dalam kebersamaam, menjadi masyarakat yang indibivualistis dan apatis.

Harus ada upaya yang sitematis pula untuk mengantisipasi perubahan-perubahan perilaku masyarakai ini, baik dari pihak pemerintah maupun masyarakat itu sendiri. Upaya sistematis itu adalah dengan sengaja menstimulasi agar kualitas interaksi sosial antar individu dalam kelompok (dalam keluarga), antar kelompok dengan kelompok (dalam Banjar, istitusi pemerintah), sebagai modal sosial, yang sangat diperlukan untuk memelihara hasil pembangunan yang sudah dicapai oleh pemerintah untuk masyarakatnya. Tidak bisa dipungkuri, bahwa dewasa ini kualitas smsrt-phone yang dimiliki oleh seseorang menunjukkan prestise sosial. Sehingga para orang tua dengan sengaja memberikan benda ini kepada anakanaknya, tanpa mempertimbangkan tingkat usia dan perkembangan psikologis. Disadari atau tidak, tindakan ini adalah awal melemahnya kualitas interaksi sosial antara anak dan orang tuanya. Demikian seterusnya sampai ke tataran terbentuknya sifat individualis dan apatis bagi anak-anak. Hal yang sama, terjadi juga pada orang dewasa, yang akhirnya member warna pada kualitas interaksi antar kelompok dalam masyarakat.

\section{KESIMPULAN DAN REKOMENDASI}

Berdasarkan paparan di atas, dapat disarikan sebagai kesimpulan akan pembahasan yang telah diuraikan di atas, yaitu: 1). Kualitas interaksi sosial dalam masyarakat Bali adalah modal sosial yang kontribusinya tidak kecil dalam pembangunan manusia seutuhnya,seperti apa yang diamanatkan oleh tujuan pembangunan bangsa Indonesia. 2). Modal sosial masyarakat Bali secara hirarkis terbentuk mulai dari anutan Nilai-nilai yang ditanamkan sejak kecil, yang selanjutnya akan membentuk norma sosial yang diakui dan dipatuhi dalam kelompok. Kebiasaan mentaati norma-norna yang ada dalam kelompok masyarakat akan menumbuhkan rasa percaya-mempercayai dalam satu kelompok. Terbentuknya trust di dalam kelompok akan menyebabkan keingnan untuk salung membantu dalam saling bertukar kebaikan dalam kelompok; tingkar resiprocity yang tinggi dalam masyarakat akan menunbukan partisipasi dalan jalinan anngita masyarakat dan membentuk jaringan sosial. Kekentalan hubungan sosial masyarakat akan menumbuhkan tindakan proaktif dalam masyarakat, yaitu tidak saja memang 
berpatisipasi, tetapi proaktif mendahului melakukan tindakan yang kondusif bagi kesejarteraah dan keamanan dalam masyarakat.

Satu hal yang menjadi rekomendasi dari tulisan ini, kepada masyarakat maupun pemerintah sebagai pelaku pembangunan yaitu: hendaknya member prosi yang seimbang dalam pengalokasian dan memanfaatan modal pembangunan yaitu yang disebut sebagai economic capital, human capital, dan social capital. Karena peran ketiga jenis midal ini dalam pembangunan adalah inhern, tidak terpisahkan dan saling menentukan.

\section{REFFERENSI}

Hasbullah, Jousairi. 2006. Social Capital: Menuju Keunggulan Budaya Manusia Indinesia. Jakarta: MR-United Press Jakarta

Kasali, Rheinald. 2018. The Great Shifting. Jakarta: PT Gramedia Pustaka Utama.

Kuncoro, Mudrajad. 2012. Perencanaan Daerah, Bagaimana Membangun Ekonomi Lokal, Kota dan Kawasan. Jakarta: Salemba Empat. 